\title{
THE PERSPECTIVE OF E-BANKING IN SMALL BUSINESS BANKING SECTOR
}

\author{
Duško Ranisavljević1, \\ Zoran Jović ${ }^{2}$
}

${ }^{1}$ Marfin Bank,

Dalmatinska 22, Belgrade, Serbia

${ }^{2}$ Singidunum University,

32 Danijelova Street, Belgrade, Serbia

\section{Correspondence:}

Duško Ranisavljević

e-mail:

dusko.ranisavljevic.12@singimail.rs

\begin{abstract}
:
Small Business Banking (SBB) segment is one of the most important segments of the banking sector in Serbia because it includes different sectors such as entrepreneurs, micro and small enterprises sectors. SBB segment is the sector with the highest growth in the post-transition period. This sector is attractive for banks because of its profitability and risk diversification. E-banking is becoming increasingly important in business correspondence between banks and SBB customers. E-banking platforms, in addition to the functions of payment transactions, become an advanced communication channel when applying for micro loans in the SBB segment. This paper discusses the potential for development of advanced e-banking channels of communication in the SBB segment, with reference to the advantages and disadvantages as well as the risks of implementing this system. It compares the commercial banks in the domestic banking market according to the criteria and effects of e-banking in the SBB segment. The conclusion is that the application of this concept reduces operating costs of banks, increases profitability, but it also increases the risk of loans. Commercial banks should gradually and cautiously approach the implementation of e-banking in the credit process in the SBB segment, because it may cause an increase in the percentage of non-performing loans.
\end{abstract}

Key words:

e-banking, credit process, payment transactions, operational risk.

\section{INTRODUCTION}

In the post-transitional period, in almost all strategies of economic recovery in the countries of South East Europe, the sector of small and medium businesses and entrepreneurs assumes the most important place.The reason for this lies in the fact that this sector is recognized as a sector which is adaptable to new market requirements, new technologies, and which can also have the greatest impact on reducing unemployment. For commercial banks in Serbia, SBB sector is being increasingly recognized as the sector which deserves the most attention.

In the period of economic growth (2005-2008), there was a noticeable orientation of the domestic banking market towards corporate clients (medium and large businesses), while small businesses and entrepreneurs were not the priority clients for most banks. Corporate clients had special 
conditions in most of the banks, such as lower payment system costs, lower interest rates for credit loans, as well as lower costs for other banking operations. It is safe to say that in the mentioned period, SBB customers did not have equal treatment with other client groups. The global economic crisis has left its mark in the domestic banking sector as well. As expected, primarily corporate client decreased their economic activity, which led to SBB customers becoming the most important group of clients both for banks and other institutions.

Over the last few years, there has been a decreasing trend in interest rates for SBB sector as the result of other measures by both state authorities and commercial banks. Commercial banks are increasingly recognizing the importance of SBB segment, and besides adjusting the credit policy, SBB segment is being offered more and more favorable payment system tariffs as well as more functional and more efficient communication channels. Until a few years ago, it was almost unthinkable that commercial banks would provide information solutions for SBB customers, such as automated cash payments, electronic orders at any given time, online applications for loans etc. All this leads to a reduction in operating costs of banks, and the time will show whether and to what extent it will increase business risks.

A study of Basel Committee for Banking Supervision came to a conclusion that: E-banking increases banks' dependence on information technology, thereby increasing the technical complexity of many operational and security issues and furthering a trend towards more partnerships, alliances and outsourcing arrangements with third parties, many of whom are unregulated. This development has led to the creation of new business models involving banks and non-bank entities, such as Internet service providers, telecommunication companies and other technology firms [1].

This paper will analyze the advanced information solutions in the communication of commercial banks and SBB customers, their representation in the national banking sector, and the risks that these systems cause.

\section{CORRESPONDENCE BETWEEN COMMERCIAL BANKS AND SBB SECTOR IN THE REPUBLIC OF SERBIA}

Traditional banking involves either daily or frequent contact between customers and bank employees. Moving the payment system to commercial banks (2002/2003), clients were directed to specific commercial banks, and since then banks have been in daily contact with their customers. With the arrival of a great number of foreign banks in the last ten years, domestic banking sector has been significantly modernized. Commercial banks have introduced various platforms for e-banking payment system. In the beginning these were simple applications, with limited possibilities. They were only able to carry out certain transactions under certain conditions. The first innovative e-banking solutions in the domestic banking market for the correspondence with business customers were given by Pro Credit, Raiffeisen Bank and Bank Intesa, then Uni credit, Societe Generale, Hypo Bank and EFG Eurobank and then the others, mostly the banks with majority foreign ownership.

Today, almost all commercial banks in the domestic banking market have their own developed e-banking platforms for dinar and foreign currency payments. Ebanking as well as standard payment system in bank premises is now in compliance with the payment clearing system of the National Bank of Serbia, which means that it is done in the manner and in the dynamics of the standard money orders.

As the number of users of e-banking in SBB segment increased over time, commercial banks have begun to recognize other advantages of this system. E-banking itself, as a banking service, has become more accessible, particularly when it comes to its price, but also in simplicity of usage. Expensive routers have been replaced with universal readers, which has enabled clients of several banks to use parallel e-banking, without increasing the fixed costs.

Furthermore, the platforms themselves have been customized for SBB clients of average "computer literacy", so the number of users has increased considerably. Finally, the price of e-banking and payment system tariffs of commercial banks have become more competitive in relation to the tariffs of "standard" payments system.

After checking the official payment system tariffs of commercial banks in Serbia (which are available on the websites of all banks), it can be seen that the average payment system tariffs are $30-40 \%$ lower compared to the rates of standard payment system. In addition to lower fees, banks also allow SBB customers to send orders 24 hours a day, finalize the order just before the last clearing (after the official working hours of banks), have a statement copy at any time, work with multiple accounts simultaneously using one digital certificate, save time etc.

In this way, banks encourage customers to use electronic payments in large numbers, because of the indirect savings in operating costs. This means that the banks need 
fewer and fewer employees in the payment system. Some of these employees can be relocated to the front office, to the position of loan advisors because the increase in sales of products and bank services is the main business mission of commercial banks today. However, according to official indicators of operating expenses of banks rose in the first three quarters of 2015 compared to 2014 by $8.5 \%$ [2].

In addition to e-banking, commercial banks also offer other solutions for SBB users, such as mobile banking, non-stop through the use of ATMs for payment and cash withdrawal etc.

\section{THE ANALYSIS OF E-BANKING AS A CHANNEL OF CORRESPONDENCE BETWEEN BANKS AND SBB SEGMENT}

Credit process in SBB segment in majority of banks is uniform and determined by both NBS regulations and policies of the banking group to which a bank belongs.

The basic rule of a high-quality credit analysis implies that a bank gets to know their client well. Unlike credit analysis of individuals where the most parameters are measurable even without "the presence of the client," with analyzing SBB credit requests the presence of the client in a commercial bank or vice versa, a commercial bank with the client is necessary.

In order to analyze the possibilities of implementing the loan process via e-banking platform in SBB segment, we should first analyze the functionality of the standard SBB loan process.

Basic phases of a loan process with SBB customers are:

- The application (request) for a loan by the client;

- Collection and presentation of the documentation (balance sheet reports, assessment of collateral, etc.);

- Analysis and making the decision on the request;

- Writing a contract and the establishment of collateral;

- Loan disbursement, monitoring and repayment;

The traditional (conservative) banking assumes direct communication between a client and a bank in the first and second stage of the loan process. In that way a commercial bank acquires a realistic insight into the client's business.

Most often the client is visited in their business base, and balance sheets and other business indicators are compared on-site. This provides a realistic picture of the benefits and possible drawbacks in the client's business activities.

As there are 30 banks in the domestic banking market, and the demand for loans in all segments including SBB segment is lower than in previous years, some banks are trying to "simplify" the credit process in SBB segment, and one way to do it might be the use of e-banking platform.

In this paper, we analyze the e-banking platforms as well as e-marketing in 5 major commercial banks that, according to the criteria of the net asset balance sheet, have a total market share in the amount of 54.27\% (1632.4 from 3007.5 billion rsd-on day 26.11.2015. according to the NBS) [3].

The following review provides an overview of the net asset balance sheet of banks mentioned:

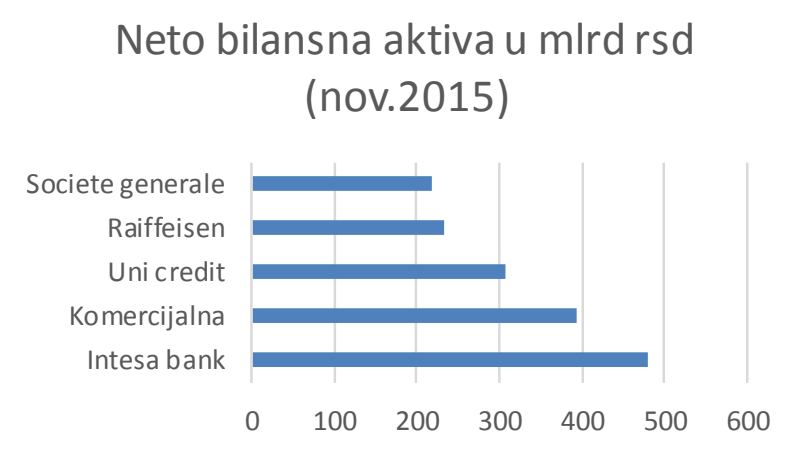

The analysis in this paper was done in two directions. First, we analyzed the e-banking platforms and the system of functioning of the credit process with SBB clients without going to the bank, i.e. electronic loan applications. The quality and intelligibility of the presentation of bank's offers, which should be comprehensible to a customer of the average information and financial literacy, are also analyzed. Channels for communication for SBB clients are compared through the official bank presentations in three aspects:

A - how developed e-banking platform is for payment system;

$B$ - efficiency of e-marketing;

C - how developed credit channel of communication is for SBB loan applications;

The results of both analyses should reveal which commercial banks have the most advanced system of electronic communication with SBB clients, and whether they are actually the banks with the best business indicators. 
Each of these criteria in the first analysis carries the rank of 1-3, with the rank "1" being the most efficient implementation of e-banking and e-marketing for SBB customers, according to the author, then the rank 2 which is slightly less efficient, and the lowest ranking is 3 . The average of all three gives the final coefficient that determines the ranking of a particular bank. According to the above-given criteria, the analysis of the listed commercial banks provided the following results (Table 1):

\begin{tabular}{lcccc}
\hline \multicolumn{1}{c}{ Bank } & A & B & C & koef. \\
\hline Intesa banka & 1 & 2 & 2 & 1.67 \\
\hline Komercijalna & 1 & 2 & 3 & 2 \\
\hline Uni credit & 2 & 3 & 3 & 2.66 \\
\hline Raiffeisen & 1 & 1 & 2 & 1.3 \\
\hline Societe generale & 1 & 2 & 3 & 2 \\
\hline
\end{tabular}

Table 1.

As can be seen in the above-given table, the analysis showed that Raiffeisen bank is a commercial bank that has made the greatest progress in accordance with the given criteria [4], followed immediately by Intesa Bank [5], Komercijalna [6] and Societe Generale [7].

The coefficient or the ponder of the results according to the three given criteria determines the final ranking of the efficiency of e-banking and e-marketing concepts. All the banks have an efficient operational system of electronic payments. Many banks have introduced the possibility of connecting to state institutions (such as the tax authorities), thus expanding the possibilities for the users. The greatest progress is estimated to be in the foreign exchange electronic payments, where many innovations and benefits have been introduced, primarily in the flow and presentation of necessary documents (invoices, customs documents, etc.) between commercial banks and customers. It is interesting that none of these banks has an official channel for submitting applications for micro-loans or SBB loans, similar to the one for retail loans. There is a model of requests and explanations for particular SBB loan products, as well as the forms, but they still have to be physically delivered to the banks' offices, at least when it comes to SBB clients.
Popularization of such communication channel, when it comes to the SBB loan applications, would imply higher costs, and it is certain that the existing software solutions and application of classic e-banking represent significant costs for the banks.

With regard to the overall savings in the economy and society, commercial banks have not had any significant technological advances in recent years, except for the system 24/7, where the modern ATMs allow customers non-stop transactions without the standard front office. In the analysis it was not considered as an advantage for customers because it is not specifically intended for SBB customers.

The second line of analysis included the analysis of the balance sheets of presented commercial banks according to the following criteria:

A - increase / decrease in balance sheet assets;

$\mathrm{B}$ - increase / decrease in interest incomes;

C - increase / decrease in business profits (none was a money loser company);

This line of analysis gives indicators of the percentage increase or decrease of the key balance sheet items of the listed banks, in recent period. We compared the indicators for the third quarter of 2015/2014 (source NBS), because these are the most recent data provided by the NBS. The results are given in the table below (Table 2):

\begin{tabular}{lccc}
\hline \multicolumn{1}{c}{ Bank } & A & B & C \\
\hline Intesa bank & $\uparrow 0,46 \%$ & $\downarrow 2,85 \%$ & $\uparrow 73,2 \%$ \\
\hline Komercijalna & $\uparrow 3,3 \%$ & $\downarrow 11,1 \%$ & $\downarrow 63,2 \%$ \\
\hline Uni credit & $\uparrow 15,85 \%$ & $\uparrow 10,4 \%$ & $\uparrow 54,4 \%$ \\
\hline Raiffeisen & $\uparrow 0,87 \%$ & $\downarrow 11,4 \%$ & $\downarrow 10,9 \%$ \\
\hline Societe generale & $\uparrow 5,04 \%$ & $\downarrow 0,97 \%$ & $\uparrow 20 \%$ \\
\hline
\end{tabular}

Table 2.

From the table above it can be seen that all the banks in the period 2014/2015 had balance sheet assets growth, to a lesser or greater percentage. When it comes to income from interest, some banks had a growth and some a decline. Some banks even had a drop in income from both interest and profit, with balance sheet assets growth. Three banks increased their net profit. 
It should be noted that the present trends are the consequence of the fact that we compared the data from the third quarter, which is not the last quarter (quarter of final balance sheet). In practice, this implies frequent change of indicators, so it is possible that the bases of indicators for the previous year change for the next quarter, which led to obtaining such data. For example, the manifold increase in profit of one of the banks is the result of accounting in the previous year, which for the quarter taken in the analysis gave very little net income. The quarter in the following year which it was compared to gave regular and real net income, but the growth trend is unrealistically high.

If we compare the results from both tables, we can reach the following conclusions. The bank with the best rated e-banking and e-marketing systems for SBB customers is Raiffeisen Bank, but their business trends in the last year and a half have not been great, but certainly not bad as well. A more detailed analysis of the balances for previous years shows that the bank achieved a significant growth, and the presented results most likely show a cyclical decline.

On the other hand, the bank with the largest increase in net balance sheet assets, and the largest increase in income in the reporting period, Uni Credit Bank, according to the results of this analysis is behind the other four banks when rated by the criteria of electronic commerce and adaptability to SBB customers [8].

Intesa Bank has the best balance indicators, a significant increase in profits. It can be said that quite good e-banking system for all user groups, with advanced application solutions. Due to the good territorial dispersion of the organizational units, large networks, significant media campaigns, this bank is no need for excessive investment in some new channels of communication, although it is expected in a way, and although we can reasonably assume that there are resources for it.

Komercijalna banka and Societe Generale are similarly ranked, according to the criteria of implementation of electronic banking, but they are quite different in terms of business results. The first one has had a significant decline in profitability, while the other one has had a significant growth.

\section{CONCLUSION}

Previous analysis points to the basic conclusion that business results of the banks are not crucial for new innovative solutions in the fields of e-banking, e-marketing or new application models of communication not only with SBB clients, but with other client groups as well.

Despite recognizing the importance of SBB segment in banks' business activities, conservative banking, i.e. traditional approach to resolving loan applications and processing of credit applications, has still remained dominant.

Our research has shown that the banks can save time and operating costs only at the stage of loan application, while in the micro business, due to the complexity of the process and the necessity of observing business clients from several aspects, simpler scoring models, or unified credit procedures, like retail loans, on-line loans or socalled "without going to the bank" loans are not possible.

Intelligibility of communication channels, then security, convenience, accuracy and speed are the most important for the perception of usefulness of an e-banking user [9].

In the short term, the sudden and uncontrolled popularization of applications which, via the Internet and other solutions, shorten the process of consideration of a client's business activities, can cause savings in operating costs, which would improve the performance indicators. There are fears that in the medium and long term, such loans could become problematic.

There is not enough affordable data in order to perform a more detailed analysis of the possible connection between the percentage of problematic loans and the level of e-banking in the SBB segment, but the risks that may occur are certainly not negligible.

The final conclusion is that commercial banks initiate the credit process electronically (sending offers, pre-approval decision on the loan application), so it can be expected that such a model of communication between SBB customers and banks will become common in a relatively short period of time, in the same way in which electronic banking system has become a widespread system wit lots of features and affordable to all client groups.

\section{REFERENCES}

[1] Risk Management Principles for Electronic Banking, Basel Committee on Banking Supervision, July 2003, str.6.

[2] Bankarski sektor u Srbiji, NBS izvestaj NBS III tromesečje 2015 str 11

[3] NBS bilansi banaka:

http://www.nbs.rs/internet/latinica/50/50_5.html

https://www.raiffeisenbank.rs/mala-privreda/elektronsko-bankarstvo/elektronsko-bankarstvo/raiffeisenonline.1415.html 
http://www.bancaintesa.rs/privreda/elektronskoposlovanje.1711.html

http://www.kombank.com/elektronsko-bankarstvo

http://www.societegenerale.rs/index.php?id=210

https://www.unicreditbank.rs/rs/pi/racun/e-bank.html
[4] Internet-based e-banking and consumer attitudes: an empirical study, Ziqi Liao, Michael Tow Cheung, 2016, Elsevier 